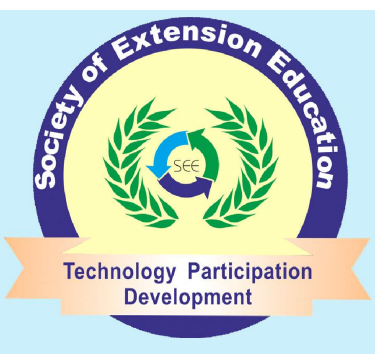

Research Note

\section{Indian Research Journal of Extension Education}

ISSN: 0972-2181 (Print), 0976-1071 (Online)

NAAS Rating : 5.22

Journal homepage: seea.org.in

https://doi.org/10.54986/irjee/2022/jan_mar/146-150

\title{
People's Participation in Farm Pond Programmes in Dry Land Areas of Tamil Nadu
}

\author{
Anitha Pauline, A. ${ }^{1}$, K. Mahandrakumar ${ }^{2}$ and C. Karthikeyan ${ }^{3}$ \\ 1. DST Women Scientist, 2 \& 3. Prof. Agricultural College and Research Institute, Madurai, \\ Tamil Nadu Agricultural University, Coimbatore. \\ Corresponding authore-mail : anithapauline.agri@gmail.com \\ Paper Received on September 15, 2021, Accepted on Novembe 20, 2021 and Published Online on January 01, 2022
}

\begin{abstract}
People's participation in planning, implementation and maintenance stage is important for making any programmes successful. Realizing it, Government of India (2011), issued a Common Guidelines for Watershed Development Projects, Revised Edition, 2011 in which participation of beneficiary farmers was made as mandatory. Hence, here an attempt has been made to study the extent of participation of beneficiaries in involvement of farm pond programmes under three stages such as planning, implementation and maintenance were studied. The study was conducted during 2020 in dry land areas of Tamil Nadu to measure the extent of people's participation in farm pond development programme. The results revealed that overall participation Index score was 64.75 per cent. It means that moderate level of participation was observed among the farmers in farm pond development programmes. Further it is noted that high level of participation was exhibited by farmers in planning stage $(72.12 \%)$ and moderate level was exhibited by farmers in implementation stage (63.78\%) as well as maintenance stage (58.36\%) of farmers in farm pond programmes. It means farmers were participated and contributed more during planning followed by implementation and maintenance stages of programme.
\end{abstract}

Key words: Dry land; People's Participation Index; Farm ponds.

$\mathbf{P}_{\text {eople's participation is, however, not a new idea }}$ in India. In fact, it emerged long ago in the vision and actions of Tagore and Gandhi. Rural masses as development actors were the central feature of their rural reconstruction programmes (Santhanam et. al. 1982). According to (Verhagen 1980), "participation is generally presented as the active involvement of target groups in the planning, implementation and control programmes and projects and not merely their passive acquiescence in performing predetermined tasks, not merely their exploitation in order to reduce the labour cost. Participation guarantees that the beneficiaries' own interests are taken into account. This enhances the likelihood that programmes and projects will prove effective in meeting felt development needs and that participants share equitably in all benefits."

Participatory approach is essential in the planning and development of the watershed management programme so that it becomes the peoples programme with the government participating in it as a facilitator only. Active people's participation is, therefore, highly critical in the success of the watershed program (Kerr et al. 2002 and Joshi et al. 2005). Farm pond construction is one of the important components of 
watershed approach.

The Govt. of Tamil Nadu is providing $100 \%$ subsidy for construction of farm ponds. The scheme started during 2015 and it was well received by the farmers in dry land areas of Tamil Nadu. These ponds helped to increase the groundwater in the area and to divert the available rainwater for irrigation. The government provides between Rs 60,000 and Rs 1 lakh based on certain norms. The project is being implemented by the Department of Agricultural Engineering, Department of Horticulture and Department of Animal Husbandry. This gives a three-pronged benefit to farmers. In addition to getting water for cultivation, it also helps in raising fish and growing good cattle grass on the banks of the pond.

According to (Bagdi and Kurothe, 2014) Stakeholders' participation at the time of planning in farm pond development programme is much needed to take decisions because the programme should be according to the basic needs of them. The local people should take interest and participate also in implementation of programme by contributing labour and money Participation in maintenance stage is required because without protection and care by the local people the programme will not be successful. The involvement of local people in programme evaluation is also necessary, so that it may provide points to be considered for improvement in future programme planning. Thus, the present research study was framed to measure the extent of people's participation in farm pond programme in dry land areas of Tamil Nadu.

\section{METHODOLOGY}

Generally farm ponds are constructed under various Government schemes such as Integrated Watershed Management Programme (IWMP), Mahatma Gandhi National Rural Employment Guarantee Programme (MGNREGA), Mission on Sustainable Dry land Agriculture (MSDA), National Horticulture Mission (NHM), NABARD assisted watershed programmes and various agencies involved for construction of farm ponds such as Department of Agriculture, Department of Horticulture, Department of Agriculture Engineering, District Watershed Development Agency (DWDA) and Non Government Organizations (NGOs).

The present study was conducted during 2020 in four districts of Tamil Nadu. i.e. Madurai, Virudunagar,
Ramanathapuram and Sivagangai. These districts were purposively selected for two reasons. According to Tamil Nadu State Land Resources Report 2017, these four districts had more area under dry lands in southern zone of Tamil Nadu and the rainfall is scarce and erratic. Multi-stage sampling procedure adopted for the study. In first stage, from each selected district two blocks were purposively selected based on more number of farm ponds and finally eight blocks were selected for the study. From each selected blocks 2 villages were selected. Totally 16 villages were included for the study. Samples of 30 farmers from each block were considered. Only the farmers who owned more than three years old farm pond alone included for the present study. Totally 240 farmers with farm ponds were randomly selected. Data were collected through pretested interview schedule. The data were analyzed by using appropriate statistical tools and the significant findings are given here under.

Further care was taken in the selection of sample farmers, to provide proper representation of the large, medium, small and marginal farmers. The data for the study was collected from both primary and secondary sources. The primary data were collected through a structured schedule, informal interviews (using detailed checklists), key informant interviews and observation. Secondary data and information were collected from DWDA (District Watershed Development Agency), DRDA (District Rural Development Agency), Agriculture Engineering Department, Block Development Officers (BDOs), and selected NGOs of the selected districts.

Extent of participation of farmer's in farm pond programmes : People's participation in planning, implementation and maintenance stage is important for making any programmes successful. Realizing it, Government of India, 2011 issued a Common Guidelines for Watershed Development Projects, Revised Edition, 2011 in which participation of beneficiary farmers was made as mandatory. Hence, here an attempt has been made to study the extent of participation of beneficiaries in involvement of farm pond programmes under three stages such as planning, implementation and maintenance were studied.

A methodology for measuring the participation was done through the statements which govern the activities in the above-mentioned stages pursuing through the 
literature four statements for each stage was identified and thus there were 12 statements were framed. Further, the responses against each statement were attained through three categories of responses such as spectator, facilitator and contributor and the score 1,2 and 3 was assigned respectively. The extent of people's participation in farm pond development programme was measured with help of People's Participation Index (PPI) developed by (Bagdi, 2002) was used with slight modification and the results are presented below.

WPI $=\frac{\text { Mean Participation Score }(\mathrm{P})}{\text { Max. } \text { Participation Score }} \times 100$

Where,

$$
\mathrm{P}=1+\frac{\sum_{\mathrm{J}=1}^{\mathrm{N}} \mathrm{Pi}}{\mathrm{N}}
$$

$P i=\sum_{I=1}^{K}(P P j+P I j+P M j)$

$\mathrm{Pi}=$ Total participation scores obtained by individual respondent in planning, implementation and maintenance.

$\operatorname{PPj}=$ Total scores obtained by a respondent due to participation in programme planning;

$\mathrm{PIj}=$ Total scores obtained by a respondent due to participation in programme implementation;

PMj = Total scores obtained by a respondent due to participation in programme maintenance;

$\mathrm{K}=$ Total number of statements on which responses of the respondents were recorded;

$\mathrm{N}=$ Total Number of respondents
Categorization of PPI : The PPI value calculated in farm pond development programme can also be categorized into three categories as suggested by the author based on the normal distribution curve values as given below (Table 1).

Categorization of people's participation according to normal distribution curve values :

Normal distribution PPI value People's participation curve range range category

$<$ Mean-S.D. $\quad 0$ to $34.13 \quad$ Low level

Mean-S.D. $\quad 34.14$ to 68.26 Moderate level

to Mean + S.D.

$>$ Mean + S.D. $\quad 68.27$ to $100 \quad$ High level

\section{RESULTS AND DISCUSSION}

People's participation in farm pond programmes : The extent of people's participation in farm pond programme was measured using participation index and the results are presented follow.

Participation in planning stage: Table 1 presents the statements regarding farm pond programme in planning stage and frequency of respondents towards them. The data revealed that majority of farmers $(80.42 \%)$ participated as spectator in planning meetings regarding awareness of farm pond programme. More than threefourth of the respondents $(76.25 \%)$ have actively participated in training and exposure visits as contributor.

Table 1. Activity-wise contribution People's participation in farm pond programmes $(\mathbf{N}=\mathbf{2 4 0})$

\begin{tabular}{|c|c|c|c|c|}
\hline Statements & Spectator & Facilitator & Contributor & $\operatorname{PPI}(\%)$ \\
\hline \multicolumn{5}{|l|}{ Planning stage } \\
\hline Participation in awareness meeting regarding farm pond programmes & 193(80.42) & $10(4.17)$ & $37(15.41)$ & 45.00 \\
\hline Visiting PIAs periodically to construct farm pond & $70(29.16)$ & $45(18.76)$ & $125(52.08)$ & 74.30 \\
\hline Participation in action plan meetings & $64(26.67)$ & $12(5.00)$ & $164(68.33)$ & 80.56 \\
\hline Participation in training programme and exposure visit & $25(10.42)$ & $32(13.33)$ & $183(76.25)$ & 88.61 \\
\hline Total (\%) & 36.67 & 10.31 & 53.02 & 72.12 \\
\hline \multicolumn{5}{|l|}{ Implementation stage } \\
\hline Participation in deciding the location and design of farm ponds & $86(35.83)$ & 15464.17) & - & 54.72 \\
\hline Provide material/ labor/ money to farm pond construction & $80(33.33)$ & - & $160(66.67)$ & 77.77 \\
\hline Supervise construction work during implementation stage & $32(13.33)$ & 208(86.67) & - & 62.22 \\
\hline Motivate your fellow farmers to participate in farm pond construction & $45(18.75)$ & $195(81.25)$ & - & 60.42 \\
\hline Total $(\%)$ & 25.31 & 58.02 & 16.67 & 63.78 \\
\hline \multicolumn{5}{|l|}{ Maintenance stage } \\
\hline Consult the PIA officers to learn about repair the farm pond structures & $132(55.00)$ & $108(45.00)$ & - & 48.33 \\
\hline Motivate your fellow farmers to participate in maintenance of farm ponds & $101(42.08)$ & $139(57.91)$ & - & 52.63 \\
\hline Contribute own labor towards repair and maintenance of farm pond & $119(49.58)$ & - & $121(50.42)$ & 66.94 \\
\hline Contribute any money towards repair and maintenance of farm pond & $124(51.66)$ & - & $116(48.33)$ & 65.55 \\
\hline Total $(\%)$ & 49.58 & 25.73 & 24.68 & 58.36 \\
\hline
\end{tabular}


About 70 per cent of respondents contributed ideas $(68.33 \%)$ in action plan meetings and more than half of the respondents $(52.08 \%)$ periodically visited PIAs (Programme Implementing Agency) to get benefit from the farm pond programme.

Table 1 further revealed that overall People's Participation Index (PPI) was calculated as 72.12 per cent in planning stage of farm pond development programmes. It means high level of participation was exhibited by farmers in planning stage of the programme. Further it is noted that more than half of the respondents $(53.02 \%)$ participated as contributor followed by more than one third (36.67\%) of the respondents participated as spectator and one-tenth $(10.31 \%)$ of respondents participated as facilitator in planning stage of farm pond programme.

Participation in implementation stage: The data in Table 1 revealed that more than half of the farmers participated as facilitator in following stages such as made supervision during construction of farm ponds $(86.67 \%)$, motivated fellow farmers to participate in farm pond construction $(81.25 \%)$ and participated in deciding the location and design of farm ponds $(64.17 \%)$. More than two-thirds $(66.67 \%)$ of the respondents have contributed material/ labor/money to farm pond construction.

Table 1 further revealed that more than half of the respondents $(58.02 \%)$ participated as facilitator followed by one - fourth $(25.31 \%)$ of the respondents participated as spectator and one-fifth (16.67\%) of respondents participated as contributor during implementing stage of farm pond programme. The overall People's Participation Index (PPI) was calculated as 63.78 per cent in implementing stage of farm pond development programmes. It means that moderate level of participation was observed among the farmers during implementation stage of programme.

Participation in maintenance stage : It could be inferred from the Table 1 that more than half $(57.91 \%)$ of the respondents have motivated their fellow farmers to participate in maintenance of farm ponds followed by 55.00 per cent of the respondents have not consulted the PIA officers to learn about repair and maintenance of farm pond structures and 51.66 per cent of the respondents have not contributed any labour towards repair and maintenance of farm pond structures.

Table 1 further revealed that more than half of the respondents $(49.58 \%)$ have not participated to any activities in maintenance of farm ponds and equal proportion of respondents of the respondents participated as facilitator $(25.73 \%)$ and contributor $(24.68 \%)$ respectively. The data in Table 1 revealed that the overall People's Participation Index (PPI) was computed as 58.36 per cent in maintenance stage of farm pond programmes. It means that moderate level of participation was exhibited among the respondents. The reason might be the poor socio-economic condition of farmers, small land holdings and undulating topography of the farmers for moderate participation in maintenance of farm pond development programme.

Overall People's participation in farm pond programmes: The overall participation of farmers in farm pond development programmes was calculated and the results are presented below.

The data in Table 2 shows that the overall participation by farmers in farm pond Development Programmes exhibited moderate level as calculated pooled PPI value 64.75 per cent. It means that moderate level of participation was observed among the farmers in farm pond development programmes. These findings are in agreement with the findings of Deshmukh and Kadam (2018) and Singh et al. (2015). The reason might be medium level of adoption farm ponds technologies, poor socio-economic status, uneven distribution of rainfall and frequent occurrence of drought leads to moderate level of participation among the respondents.

It was also revealed that high level of participation was exhibited by farmers in planning stage $(72.12 \%)$ and moderate level was exhibited by farmers in implementation stage $(63.78 \%)$ as well as maintenance stage $(58.36 \%)$ of farmers in farm pond programmes. It means farmers were participated and contributed more

Table 2. Overall People's participation in farm pond programmes

\begin{tabular}{lllll}
\hline Level's of participation & Spectator & Facilitator & Contributor & PPI(\%) \\
\hline Planning & 36.67 & 10.31 & 53.02 & 72.12 \\
Implementation & 25.31 & 58.02 & 16.67 & 63.78 \\
Maintenance & 49.58 & 25.73 & 24.68 & 58.36 \\
Overall participation score & 37.18 & 31.35 & 31.46 & 64.75 \\
\hline
\end{tabular}


during planning followed by implementation and maintenance stages of programme. It was found out from the study that in programme planning stage the majority of farmers participated in planning meetings and they also participated in training and exposure visit in programme planning stage. In implementation stage majority of farmers motivated their fellow farmers to participate in farm pond development programme and they also shared information or experience with their fellow farmers after participating in planning meetings. Further, they have contributed their own labour/ideas/ money or material towards construction of farm pond structures in their fields and also made supervision during implantation programme. In maintenance stage the majority of farmers motivated to their fellow farmers for repair and maintenance of farm pond structures.

From the above Table 2, it is concluded that, more than one-third of the respondents (37.18\%) participated as spectator and equal proportion of respondents participated as contributor (31.46\%) as well as facilitator $(31.35 \%)$ respectively throughout the farm pond development programme.

\section{CONCLUSION}

It is concluded that high level of participation was exhibited by farmers during planning stage $(72.12 \%)$ and moderate level was exhibited by farmers in implementation stage $(63.78 \%)$ as well as maintenance stage $(58.36 \%)$ of farmers in farm pond programmes. It means farmers were participated and contributed more during planning followed by implementation and maintenance stages of programme. The maintenance of farm ponds is very much essential to increase the life span of farm pond. More than one-third of the participants were participated as spectator during farm pond programme. Extension functionaries increase the awareness of farmers through Capacity building training about the long-term benefits of the farm pond programmes. Government has many programmes for agricultural and rural development which have not reached the target groups up to a satisfactory level. Therefore, by using proper methods attempts should be made to motivate them through an emphasis on the deprived need areas.

\section{ACKNOWLEDGEMENT}

The authors are very much thankful to the DST, New Delhi for sponsoring to conduct study on "Performance Evaluation of farm ponds in dry land areas of Tamil Nadu.

\section{CONFLICTS OF INTEREST}

The authors declare that they have no conflicts of interest.

\section{REFERENCES}

Bagdi, G. L. (2002). People's participation in soil and water conservation for sustainable agricultural production in the Antisar watershed of Gujarat (Doctoral dissertation). Faculty of Home Science, The M. S. University of Baroda, pp. 123.

Bagdi, G. L. and R. S. Kurothe. (2014). People's participation in watershed management programmes: Evaluation study of Vidarbha region of Maharashtra in India. International Soil and Water Conservation Research, Vol. 2, No. 3, 2014, pp. 57-66.

Kerr, J. et al. (2000): An Evaluation of Dry Land Watershed Development Projects in India, Environment and Production Technology Division, International Food Policy Research Institute 2033, K Street, N.W Washington, D.C. 20006 U.S.A.

Verhagen, K. (1980). How to promote people's participation in rural development through local organizations. Review of International Cooperation, 73 (1), 28.

Joshi, P.K. et al. (2008): Report no. 46 on Impact of Watershed Program and Conditions for Success, A Meta Analysis Approach, International Crops Research Institute for the Semi- Arid Tropics, Andhra Pradesh.

Deshmukh, K.U. and Kadam, R.P. (2018). Correlates of Extent of Participation and Impact of National Watershed Development Programme by the Beneficiaries. Indian Res. J. Ext. Edu., 18 (4) : 65-68.

Santhanam, M.L., Yogananda, S. C., \& Vijayakumar, S. (1982). Human and social factors in people's participation. J. Rural Devel., $1(5): 770-831$.

Singh, S., S. Kushwah, V.B. Singh and O.P. Daipuria (2015). Factor affecting the participation of rural women in agricultural activities. Indian Res.J.Ext. Edu., 15 (1):81-83. 